\title{
Appraisal of ${ }^{15} \mathrm{~N}$ enrichment and ${ }^{15} \mathrm{~N}$ natural abundance methods for estimating $\mathrm{N}_{2}$ fixation by understorey Acacia leiocalyx and A. disparimma in a native forest in subtropical Australia
}

\section{Shahla Hosseini Bai • Fangfang Sun • Zhihong Xu • Timothy J Blumfield • Chengrong Chen • Clyde Wild}

\section{S. Hosseini Bai $(\square)$}

Environmental Futures Centre, School of Biomolecular and Physical Sciences, Griffith University, Nathan, Brisbane, Queensland 4111, Australia

e-mail: $\underline{\text { s.hosseini-bai@griffith.edu.au }}$

\section{F.F. Sun}

Research Centre for Quality, Safety and Standard of Agricultural Products, Guangdong Academy of Agricultural Sciences, Guangzhou 510640, China

\section{Z. H. Xu • T. J. Blumfield}

Environmental Futures Centre, School of Biomolecular and Physical Sciences, Griffith University, Nathan, Brisbane, Queensland 4111, Australia

C. R. Chen

Environmental Futures Centre, School of Environment, Griffith University, Nathan, Brisbane, Queensland 4111, Australia

C. Wild

Environmental Futures Centre, School of Environment, Griffith University, Gold Coast, Queensland 9726, Australia

\footnotetext{
Abstract

Purpose: It is anticipated that global climate change will increase the frequency of wildfires in native forests of eastern Australia. Understorey legumes such as Acacia species play an
} 
important role in maintaining ecosystem $\mathrm{N}$ balance through biological nitrogen fixation (BNF). This is particularly important in Australian native forests with soils of low nutrient status and frequent disturbance of the nutrient cycles by fire. This study aimed to examine ${ }^{15} \mathrm{~N}$ enrichment and ${ }^{15} \mathrm{~N}$ natural abundance techniques in terms of their utilisation for evaluation of $\mathrm{N}_{2}$ fixation of understorey acacias and determine the relationship between species ecophysiological traits and $\mathrm{N}_{2}$ fixation.

Materials and methods: A trial was established at two Sites 1 and 2 located at Toohey Forest, Queensland, Australia, a eucalypt-dominated native forest, to examine the determination of BNF using ${ }^{15} \mathrm{~N}$ enrichment and ${ }^{15} \mathrm{~N}$ natural abundance methods. Toohey Forest is an urban forest and subjected to frequent fuel reduction burns to protect the adjacent properties. Plant physiological status was measured to determine the relationship between physiological and $\mathrm{N}_{2}$ fixation activities.

Results and discussion: Both ${ }^{15} \mathrm{~N}$ enrichment and ${ }^{15} \mathrm{~N}$ natural abundance techniques may be used to estimate $\mathrm{N}_{2}$ fixation of acacia tree species. The estimation of BNF using ${ }^{15} \mathrm{~N}$ enrichment was higher than those of the ${ }^{15} \mathrm{~N}$ natural abundance method. A grass reference plant, Themeda triandra, as well as tree reference plants provided an appropriate $\delta^{15} \mathrm{~N}$ signal. Potential $B$ values for Acacia spp. between $-0.3 \%$ and $1.0 \%$ provided an acceptable BNF estimation. This suburban forest has been located nearby busy highways leading to the $\mathrm{N}$ deposition over time with negative $\delta^{15} \mathrm{~N}$ signal. This $\mathrm{N}$ deposition may explain the separation between acacias $\delta^{15} \mathrm{~N}$ signal and that of the reference plants which would be led to the successful use of the ${ }^{15} \mathrm{~N}$ natural abundance technique. A. leiocalyx demonstrated greater $\mathrm{N}_{2}$ fixation as well as photosynthesis and instantaneous water use efficiency (iWUE) than $A$. disparimma. However, no strong relationship between plant photosynthesis and $\mathrm{N}_{2}$ fixation was observed in this study. A high-within treatment variation may have masked the relationships between plant BNF activities and photosynthesis

Conclusions: The ${ }^{15} \mathrm{~N}$ natural abundance technique is preferred to be used for future studies as it is simple and inexpensive compared to ${ }^{15} \mathrm{~N}$ enrichment method. The dependence of both species on BNF at Site 2, where fuel reduction burning had not taken place for 8 years, suggests that the frequent burning impoverished the soil and this has wider implications as higher fire frequencies are to be expected in other Australian ecosystems as a result of global climate change.

Keywords ${ }^{15} \mathrm{~N}$ enrichment method $\cdot{ }^{15} \mathrm{~N}$ natural abundance method $\cdot$ Acacia leiocalyx, $A$. disparimma $\bullet \mathrm{N}_{2}$ fixation 


\section{Introduction}

Global climate change, particularly rising atmospheric carbon dioxide $\left(\mathrm{CO}_{2}\right)$ concentration and temperature can alter rainfall patterns and distribution (Xu et al. 2009; McKeon et al. 2009); and reduce soil moisture across Australia (Jung et al. 2010). These alterations may be linked to more extreme environmental conditions such as prolonged drought and drier growing seasons and consequently more frequent fires. Prescribed burning is widely used as a forest management tool in Australia and may result in the loss of $\mathrm{N}$ through volatilisation (Crutzen and Andreae 1990; May and Attiwill 2003; Reverchon et al. 2011) and also increase the release of terrestrial carbon (C) to the atmosphere (Thonicke et al. 2010). Therefore, after a fire, fast growing understorey legumes such as Acacia species may play an important role in post-fire recovery by adding $\mathrm{N}$ through $\mathrm{N}_{2}$ fixation (Hamilton et al. 1993; Guinto et al. 2000; Reverchon et al. 2011) and increasing $C$ sequestration. Nitrogen input to the soil through $\mathrm{N}_{2}$ fixation of Acacia species, in Australia, may exceed $50 \mathrm{Kg} \mathrm{N} \mathrm{ha}^{-1}$ year $^{-1}$ depending on acacia density in the ecosystem (May and Attiwill 2003; Adams et al. 2010). With the exception of a study conducted by Guinto et al. (2000), who determined the ability of A. leiocalyx to fix atmospheric $\mathrm{N}_{2}$, there is limited published information of Acacia spp. particularly $A$. leiocalyx and A. disparimma in subtropical Australia. Quantifying the ability of these species to fix $\mathrm{N}_{2}$ will increase understanding of their contribution to Australian native forest ecosystems.

The most commonly used methods to determine $\mathrm{N}_{2}$ fixation in legumes are: the acetylene reduction assay (ARA); ${ }^{15} \mathrm{~N}$ enrichment; and ${ }^{15} \mathrm{~N}$ natural abundance (Forrester et al. 2006). Different studies have shown that the accuracy of ARA to estimate BNF may be uncertain when used in the field (Peoples et al. 1989; Unkovich and Pate 2000). ${ }^{15} \mathrm{~N}$ enrichment and ${ }^{15} \mathrm{~N}$ natural abundance are considered to be time integrated methods to determine $\mathrm{N}_{2}$ fixation under natural conditions (Boddey et al. 2000; Unkovich and Pate 2000). However, both methods have limitations under natural conditions including: alteration in the pattern of $\mathrm{N}$ uptake by trees; the different potential capacity for nodulation of plants within species; and uneven plant distribution leading to variation in the availability of resources (Hansen and Pate 1987; Ladha et al. 1993; Peoples et al. 1996). Furthermore, the determination of the $\mathrm{N}_{2}$ fixation in large plants has always been challenging due to difficulties associated with existing methodologies for large trees which could underestimate the $\mathrm{N}$ input to ecosystems (Hopmans et al. 1993). The use of ${ }^{15} \mathrm{~N}$ natural abundance method 
in agricultural ecosystems has been well established (Unkovich and Pate 2000; Somado and Kuehne 2006; Houngnandan et al. 2008; Naab et al. 2009). In Australia, this method has also been used successfully for shrub and woody legumes including: western Australia for Chamaecytisus proliferus (Unkovich et al. 2000); north Queensland for Calliandra calothyrsus (Peoples et al. 1996); and Victoria for three species of acacias (Hamilton et al. 1993; May and Attiwill 2003). However, the method was unsuccessful when applied to A. leiocalyx in subtropical Queensland (Guinto et al. 2000). Using ${ }^{15} \mathrm{~N}$ natural abundance method to estimate the percentage of BNF derived from the atmosphere (\%Ndfa) of woody plants in subtropical Australia therefore requires further investigations.

For the ${ }^{15} \mathrm{~N}$ enrichment technique, a ${ }^{15} \mathrm{~N}$-enriched fertiliser is applied to the soil and the dilution of ${ }^{15} \mathrm{~N}$ enrichment in the plant by atmospheric ${ }^{15} \mathrm{~N}$ reveals the extent of $\mathrm{N}_{2}$ fixation (Warembourg 1993). To attain the greatest accuracy, soils need to be homogeneously labelled by the fertiliser solution to provide a stable ${ }^{15} \mathrm{~N} /{ }^{14} \mathrm{~N}$ ratio (Danso et al. 1992; Warembourg 1993; Parrotta et al. 1994).

The ${ }^{15} \mathrm{~N}$ natural abundance method uses the differences between the ${ }^{15} \mathrm{~N}$ enrichment of soil and atmospheric $\mathrm{N}_{2}$ (Shearer and Kohl 1986). The ${ }^{15} \mathrm{~N}$ natural abundance technique requires well matched reference plants and accurate $B$ values, the ${ }^{15} \mathrm{~N}$ abundance of the $\mathrm{N}$ in the plant that is derived from the air, to quantify BNF(Boddey et al. 2000; Guinto et al. 2000; Gehring and Vlek 2004). Guinto et al. (2000) found no significant difference in $\delta^{15} \mathrm{~N}$ signal between Acacia spp. and the selected reference plants which led to unsuccessful use of the ${ }^{15} \mathrm{~N}$ natural abundance technique. The experiment was also conducted in a natural forest with high spatial variability. Reference plants are selected from species that naturally occur at the experimental sites and the availability of suitable plants may be a condition to using the ${ }^{15} \mathrm{~N}$ natural abundance method to evaluate BNF.

$\mathrm{N}_{2}$ fixation is an energy consuming process which may be directly linked to plant photosynthetic capacity (Lambers et al. 2008). Under frequently water limiting conditions, alteration in plant water use efficiency strategies (WUE), including stomatal closures, leaf to air vapour pressure and transpiration, may influence both $\mathrm{N}_{2}$ fixation and plant photosynthetic capacity. Hence, these parameters may be linked to each other and the ability of the plant to fix $\mathrm{C}$ through photosynthesis may control the rate of $\mathrm{N}_{2}$ fixation (Fujita et al. 1988; Imsande 1988; Aranjuelo et al. 2007).

This study aimed to (1) examine ${ }^{15} \mathrm{~N}$ enrichment and ${ }^{15} \mathrm{~N}$ natural abundance techniques in terms of their utilisation for evaluation of $\mathrm{N}_{2}$ fixation of understorey acacias; (2) evaluate the utility of the ${ }^{15} \mathrm{~N}$ natural abundance technique for future study due to its low 
cost and simplicity; and also (3) determine the relationship between species ecophysiological traits, including leaf-level photosynthesis and WUE, and $\mathrm{N}_{2}$ fixation.

\section{Materials and methods}

\subsection{Site description}

The experimental sites were situated at Toohey Forest $\left(27^{\circ} 32^{\prime} 53 \mathrm{~S} ; 153^{\circ} 03^{\prime} 21 \mathrm{E}\right)$ located in Brisbane, south-east Queensland, Australia. Toohey Forest is a remnant island of native vegetation of about 640 ha, completely surrounded by suburban sprawl. The vegetation is dry sclerophyll forest dominated by rough-barked eucalypts with an understorey usually less than $2 \mathrm{~m}$ tall consisting of grasses and shrubs. Xanthorrhoea johnsonii (Xanthorrhoeaceae) may be quite dense in the shrub layer in areas where sandstone is the parent material. Soils are redyellow podzolics with a silty loam A horizon, generally less than $10 \mathrm{~cm}$ (Catterall et al. 1987). Soil chemical and physical properties are given in Table 1. The area is classified as sub-tropical with a mean annual temperature of $27^{\circ} \mathrm{C}$ and an average annual precipitation of $1350 \mathrm{~mm}$, with the data for the study period presented in Fig. 1.

The two experimental sites have been subjected to fuel reduction burns over a period of 20 years. Site 1 was burnt in 1991, 1993 and 2008 and Site 2 was burnt in 1991 and 2001. The experiments were designed as a randomised complete block. At Site 1, treatments were two methods ( ${ }^{15} \mathrm{~N}$ enrichment and ${ }^{15} \mathrm{~N}$ natural abundance) and two species (A. disparimma and A. leiocalyx) with 5 replications per treatment. At Site 2, treatments were species $(A$. disparimma and A. leiocalyx) and plant sizes ( $<2.5 \mathrm{~m}$ and 2.5 to $4.5 \mathrm{~m}$ height) categorised as small and medium, with 5 replications per treatment. At Site 2 , only the ${ }^{15} \mathrm{~N}$ natural abundance was examined and the ${ }^{15} \mathrm{~N}$ enrichment was not practiced due to difficulties associated with making barriers for large trees. Sampling was undertaken at both Sites in April 2009, August 2009 and March 2010, defined as Seasons 1 to 3.

\section{$2.2{ }^{15} \mathrm{~N}$ enrichment technique}

A. leiocalyx and A. disparimma seedlings and with Eucalyptus planchoniana (Myrtaceae) as reference plant, all plants with height under $1 \mathrm{~m}$, were randomly selected at Site 1 . A microplot was established in the soil around each seedling. Each micro-plot was established using plastic barriers to a depth of $0.30 \mathrm{~m}$ and enclosing an area $50 \mathrm{~cm} \times 50 \mathrm{~cm}$. In March 2009, two weeks after installing the barriers, the soil within each micro-plot was labelled by $50 \mathrm{ml}$ fertiliser solution containing ammonium sulphate $\left(10.0\right.$ atom\% $\left.{ }^{15} \mathrm{~N}\right)$ at $10 \mathrm{~kg} \mathrm{~N} \mathrm{ha}^{-1}$. The ${ }^{15} \mathrm{~N}$ fertiliser solution was applied to an area $20 \mathrm{~cm} \times 20 \mathrm{~cm}$ in an area around basal diameter that 
had been equally divided into 25 squares. Each square received $2 \mathrm{ml}$ of the fertiliser solution injected to depth of $2 \mathrm{~cm}$ in the soil using a $3-\mathrm{ml}$ syringe with a terumo spinal needle $18 \mathrm{G} \times$ $31 / 2 "(1.20 \times 90 \mathrm{~mm})$. The ${ }^{15} \mathrm{~N}$ natural abundance micro-plots received $50 \mathrm{ml}$ water using the same method. To avoid $\mathrm{N}$ volatilisation, the ${ }^{15} \mathrm{~N}$ fertiliser solution was applied on a cool and cloudy day.

The percentage of $\mathrm{N}_{2}$ fixed from atmosphere (\% Ndfa) was calculated using the following equation (Fried and Middelboe 1977):

$\% \mathrm{Ndfa}=100 \times\left[1-\left(\right.\right.$ atom $\%{ }^{15} \mathrm{~N}_{\text {excess sample }} /$ atom $\left.\left.\%{ }^{15} \mathrm{~N}_{\text {excess ref }}\right)\right]$

Where:

atom $\%{ }^{15} \mathrm{~N}_{\text {excess sample }}=$ the weighted average ${ }^{15} \mathrm{~N}$ enrichment of Acacia spp.

atom $\%{ }^{15} \mathrm{~N}_{\text {excess ref }}=$ the weighted average ${ }^{15} \mathrm{~N}$ enrichment of reference plants

\section{$2.3^{15} \mathrm{~N}$ natural abundance technique}

The experiment examined A. leiocalyx and A. disparimma of different sizes. Nine different species of non- $\mathrm{N}_{2}$-fixing reference plants of a medium size at Site 2 and small size at Site 1 were used. The reference plants were categorised into two groups; consisting of eight tree species Eucalyptus planchoniana, E. psammitica, E. carnea, E. tindaliae, E. resinifera, Corymbia henryi, Angophora woodsiana (all Myrtaceae), Xanthorrhoea johnsonii and one herbaceous species, Themeda triandra (Poaceae). Each species of reference plant chosen at each plot had two replications. Angophora woodsiana was selected as reference plant for all BNF estimation using the ${ }^{15} \mathrm{~N}$ natural abundance because of its availability at both sites. Furthermore, using one reference plant for all estimations could minimise the potential error.

The value of $\delta{ }^{15} \mathrm{~N}$ was determined using the following equation:

$\delta{ }^{15} \mathrm{~N}=1000 \times\left[\left(\mathrm{R}_{\text {sample }}-\mathrm{R}_{\text {std }}\right) / \mathrm{R}_{\text {std }}\right]$

Where

$\mathrm{R}$ is the isotopic ratio ${ }^{15} \mathrm{~N} /{ }^{14} \mathrm{~N}$ of sample and standard (std) which refers to the atmospheric $\mathrm{N}_{2}$.

The percentage of $\mathrm{N}$ derived from atmospheric $\mathrm{N}_{2}(\% \mathrm{Ndfa})$ was calculated using the following equation (Shearer and Kohl 1986):

$\% \mathrm{Ndfa}=\left[\left(\delta^{15} \mathrm{~N}_{\text {ref }}-\delta^{15} \mathrm{~N}_{\text {acacia }}\right) /\left(\delta^{15} \mathrm{~N}_{\text {ref }}-B_{\text {value }}\right)\right] \times 100$

Where:

$\delta{ }^{15} \mathrm{~N}_{\text {ref }}=$ the $\delta{ }^{15} \mathrm{~N}$ value of the reference plants

$\delta{ }^{15} \mathrm{~N}_{\text {acacia }}=$ the $\delta{ }^{15} \mathrm{~N}$ value of the Acacia spp. 
$B_{\text {value }}=$ the relative isotopic abundance of Acacia spp. growing under a $\mathrm{N}$-free nutrient condition.

The $B$ values reported from a large array of sources vary from $-2.9 \%$ to $1.0 \%$ for woody plants (Shearer and Kohl 1986; Boddey et al. 2000). In the present study, different $B$ values varying from $-1.3 \%$ to $1.0 \%$ were examined to determine an applicable $B$ value for Acacia spp. under the experimental condition.

\subsection{Plant sampling and analysis}

Three fully expanded leaves of each selected Acacia species from different sizes and also from each of the reference plants were collected. The leaves were kept in separate paper bags and transferred to the laboratory. These samples were then oven dried at $50^{\circ} \mathrm{C}$ to a constant weight and ground to a fine powder by a Rocklabs ${ }^{\mathrm{TM}}$ ring grinder (Guinto et al. 2000). The resulting homogenised powder was weighed into $8 \mathrm{~mm} \times 5 \mathrm{~mm}$ tin capsules for analysis using an isotope ratio mass spectrometer (GV Isoprime, Manchester, UK). A minimum of $10 \%$ replication was used to verify the accuracy of the results. These samples were assessed for total $\mathrm{N}(\mathrm{TN}), \mathrm{N}$ isotope composition $\left(\delta{ }^{15} \mathrm{~N}\right)$ and $\mathrm{C}$ isotope composition $\left({ }^{13} \mathrm{C}\right)$ as described by Prasolova et al. (2000) and Xu et al. (2000; 2003).

\subsection{Gas exchange measurements}

Gas exchange was determined for each plant using a portable photosynthesis system (Model LI-6400, Li-Cor). Data were collected for each selected plant with three replicates per plant using a constant $\mathrm{CO}_{2}$ concentration $380 \mu \mathrm{mol} \mathrm{mol}{ }^{-1}$ and a blue-red light-emitting diodes (Model 6400-02B) adjusted at photosynthetically active radiation (PAR) $1400 \mu \mathrm{mol} \mathrm{s}{ }^{-1}$. Parameters derived from survey data were net photosynthesis $\left(A_{\mathrm{n}}\right)$, transpiration $(E)$, stomatal conductance $\left(g_{\mathrm{s}}\right)$ and intercellular $\mathrm{CO}_{2}$ concentration $\left(C_{\mathrm{i}}\right)$. The photosynthetic response to light ( $A / Q$ response curves) was also determined at various PAR varying from 1700 to 0 in 12 steps as 1700, 1400, 1100, 800, 500, 300, 150, 100, 80, 50, 20 and 0 and maximum

photosynthesis $\left(A_{\max }\right)$ derived from this curve. Instantaneous water use efficiency (iWUE) at leaf level was determined as $A_{\mathrm{n}} / E$ (Farquhar and Richards 1984). All measurements were taken on sunny days between 09:00 and 12:00.

\subsection{Statistical analysis}

Analysis of variance (ANOVA) was conducted to detect the differences in $\mathrm{N}_{2}$ fixation with respect to seasonal variation, age classes, species and also physiological parameters. The 
Tukey HSD test at $P<0.05$ was used to determine a comparison among treatment means. A paired T-test was carried out to compare means of two techniques of $\mathrm{N}_{2}$ fixation. Linear regression was carried out to indicate the relationships among $\mathrm{N}_{2}$ fixation and photosynthesis or WUE. Statistix software (Version 8) was used for all the statistical analyses.

\section{Results}

\section{1 ${ }^{15} \mathrm{~N}$ enrichment and ${ }^{15} \mathrm{~N}$ natural abundance methods}

The BNF estimation using the two methods indicated a significant difference at each sampling season $(P<0.05)$. A paired-samples T-test demonstrated that mean $\% \mathrm{Ndfa}$ determined using the ${ }^{15} \mathrm{~N}$ enrichment technique was significantly $(P<0.05, n=58)$ higher than that derived from the ${ }^{15} \mathrm{~N}$ natural abundance technique. This difference existed irrespective of acacia species or sampling season, and was about $31 \%$ higher on average using the ${ }^{15} \mathrm{~N}$ enrichment technique, compared with that of the ${ }^{15} \mathrm{~N}$ natural abundance technique.

At Site 1, BNF of A. leiocalyx and A. disparimma based on ${ }^{15} \mathrm{~N}$ enrichment technique indicated a significant difference at three sampling times $(P<0.05$, Fig. 2a). BNF of $A$. leiocalyx was significantly higher than those of A. disparimma. The estimated BNF based on ${ }^{15} \mathrm{~N}$ enrichment technique varied from $94.8 \%$ to $96.5 \%$ for A. leiocalyx and was from $83.3 \%$ to $91.8 \%$ for $A$. disparimma. At Site 1, no significant difference was detected in BNF estimation using the ${ }^{15} \mathrm{~N}$ natural abundance method for A. leiocalyx and A. disparimma with the only exception at Season 3 when BNF of A. leiocalyx was significantly higher than that of A. disparimma (see Fig. 2b). The estimated BNF based on ${ }^{15} \mathrm{~N}$ natural abundance technique was from $59.6 \%$ to $82.5 \%$ for A. leiocalyx and ranged from $35.8 \%$ to $72.0 \%$ for $A$. disparimma. At Site 2, the BNF did not vary significantly in response to plant size. The BNF of A. leiocalyx was significantly higher than that of A. disparimma at Seasons 2 and 3 $(P<0.05)$. The determination of BNF based on ${ }^{15} \mathrm{~N}$ natural abundance technique was from $75.6 \%$ to $86.2 \%$ for A. leiocalyx and varied from $80.6 \%$ to $54.5 \%$ for A. disparimma (see Fig. 2c).

\section{$3.2 \delta^{15} \mathrm{~N}$ values of acacias and reference plants}

The $\delta^{15} \mathrm{~N}$ values of A. leiocalyx, irrespective of sampling season, were less negative than those of A. disparimma, $-0.73 \%$ vs. $-1.06 \%$ respectively. However, this difference was only significant at the last sampling $(P<0.05)$. At Site 1 , the $\delta^{15} \mathrm{~N}$ differences were smaller than $2.0 \%$ (Table 2 ) on a few occasions. At Site $2, \delta^{15} \mathrm{~N}$ differences between acacia species and reference plants was $>2.0 \%$ for all selected reference plants and there was a significant 
difference in $\delta^{15} \mathrm{~N}$ between acacias and all selected reference plants, regardless of sampling seasons $(P<0.05)$.

\section{3 $B$ values}

Using a $B$ value of $-1.3 \%$ resulted in an estimation of $\% \mathrm{Ndfa}$ that was greater than $100 \%$. At Site 2, assuming $B=-1.3 \%$ resulted in $68 \%$ of all cases having the $\%$ Ndfa greater than $100 \%$ ( $n=33$ out of 48 ) while this percentage dropped to $6.25 \%$ when $B$ was assumed to be $-0.3 \%$ ( $n=3$ out of 48 ). None of the cases were greater than $100 \%$ when $B$ values were either $0.0 \%$ o or $1.0 \%$. Therefore, potential $B$ value for these two acacias could be from $-0.3 \%$ to $1 \%$. In our study, we chose B value of $0.0 \%$ to report the results of BNF determination based on the ${ }^{15} \mathrm{~N}$ natural abundance method.

\subsection{Physiological traits of both species}

A. leiocalyx had significantly higher net photosynthesis $\left(A_{\mathrm{n}}\right)$ and maximum photosynthesis $\left(A_{\max }\right)$ than $A$. disparimma $(P<0.05$, Fig. 3a and Table 3$)$, Transpiration $(E)$ of A. leiocalyx was greater when compared with that of $A$. disparimma but it was significant only at Season 1 ( $P<0.05$, Fig. 3b). Instantaneous water use efficiency (iWUE) did not vary significantly in response to plant species with the exception observed at Season 3 when iWUE of A. leiocalyx was significantly greater than $A$. disparimma $(P<0.05$, Fig. $3 \mathrm{c})$. No significant difference of $\mathrm{C}$ isotope composition $\left(\delta^{13} \mathrm{C}\right)$ between two plant species (main effect) was observed (Table 3 ). Total $\mathrm{N}(\mathrm{TN})$ of A. leiocalyx was slightly higher than that of A. disparimma. However, the difference in foliar TN between two species was only significant at Season $3(P<0.05,2.50 \%$ vs. $2.05 \%$ respectively, Table 3 ).

\subsection{Relationships among physiological traits}

A linear regression was carried out between net photosynthesis $A_{\mathrm{n}}$ and iWUE, $E$ or $C_{\mathrm{i}}$. iWUE, $E$ or $C_{\mathrm{i}}$ explained $20 \%, 35 \%$ and $17 \%$ of the variation in $A_{\mathrm{n}}(n=18, P<0.05)$. There was a positive correlation between $\mathrm{TN}$ and $A_{\mathrm{n}}$ and between $\mathrm{TN}$ and $\% \mathrm{Ndfa}\left(\mathrm{R}^{2}=0.17\right.$ and $\mathrm{R}^{2}=0.31$ respectively, $n=16, P<0.05$, Fig. 4). A linear regression was performed between $\%$ Ndfa and physiological traits including: $A_{\mathrm{n}}, E$ and iWUE for each species separately and there was a poor or no significant relationship among those variables.

\section{Discussion}

\section{1 ${ }^{15} \mathrm{~N}$ enrichment and ${ }^{15} \mathrm{~N}$ natural abundance methods}

Our results demonstrated that both ${ }^{15} \mathrm{~N}$ enrichment and ${ }^{15} \mathrm{~N}$ natural abundance were valid methods to provide quantitative estimation for $\mathrm{N}_{2}$ fixation of understorey trees, A. leiocalyxs 
and A. disparimma. The difference in the BNF estimation between the two methods, with the ${ }^{15} \mathrm{~N}$ enrichment method giving consistently higher estimates of BNF was similar to the findings of Bouillet et al. (2008). Fertilisation may have stimulated soil microbial activity and the ${ }^{15} \mathrm{~N}$ may have been mineralised or immobilised. Uptake of the newly mineralised $\mathrm{N}$ could have caused the higher estimation of BNF in the ${ }^{15} \mathrm{~N}$ enrichment (Høgh-Jensen and Schjoerring 1994). Small within-treatment variation in the ${ }^{15} \mathrm{~N}$ enrichment method may demonstrate an even distribution of $\delta^{15} \mathrm{~N}$ available in the soil of reference plants.

The determination of $\% \mathrm{Ndfa}$ based on the natural abundance method for A. leiocalyxs and A. disparimma was in agreement with values for other acacia species reported in Australia a $43 \%$ for A. melanoxylon, $48 \%$ for A. mucronata (Hamilton et al. 1993) and 59\% for A. dealbata (May and Attiwill 2003) based on the ${ }^{15} \mathrm{~N}$ natural abundance method. There was limited information regarding \%Ndfa of A. leiocalyxs and A. disparimma in Australia.

Despite the fact that \%Ndfa determination of two methods were within an acceptable range, the relationship between the two methods was poor. This was consistent with other studies (Androsoff et al. 1995; Stevenson et al. 1995). Galiana et al. (2002) reported a range of $\mathrm{N}_{2}$ fixation for A. mangium from $20 \%$ to $90 \%$ based on ${ }^{15} \mathrm{~N}$ natural abundance method. The range in our study was much narrower for both species and this variability may have been due to the within-treatment variation caused by spatial variation of mutualistic organisms (Boddey et al. 2000) or non-homogenised $\mathrm{N}$ and water availability in the soil (Stevenson et al. 1995).

Our experiment indicated that the ${ }^{15} \mathrm{~N}$ enrichment technique provided accurate and reliable estimations and demonstrated a smaller range of values compared to the ${ }^{15} \mathrm{~N}$ natural abundance method. However, it was associated with technical barriers and costs when applied to trees and tends to give higher estimates of BNF. The ${ }^{15} \mathrm{~N}$ natural abundance method was simple and inexpensive and our results clearly indicated that this method can be successfully used to determine BNF in Australian native forests despite the within-treatment variation which was probably inevitable under natural conditions.

Negative $\delta^{15} \mathrm{~N}$ values, observed in this study, were unusual for Australian native forests which normally demonstrated a level of enrichment as a result of isotopic discrimination (Blumfield and $\mathrm{Xu}$ 2003; Blumfield et al. 2006; Burton et al. 2007). Two forests in Netherland exposed to elevated $\mathrm{N}$ input for 40 years had negative $\delta^{15} \mathrm{~N}$ soil values (Koopmans et al. 1997) and negative $\delta^{15} \mathrm{~N}$ values have also been found in forest soil near a highway in Switzerland (Guerrieri et al. 2009). In the present study, negative $\delta^{15} \mathrm{~N}$ values were probably the result of atmospheric $\mathrm{N}$ deposition as this forest was an urban forest that 
was bisected by a busy motorway. Fuel combustion in vehicles was one of the major sources for $\mathrm{NO}_{\mathrm{x}}$ (Xiao and Liu 2002; Xiao et al. 2010) and the $\delta^{15} \mathrm{~N}$ in $\mathrm{NO}_{\mathrm{x}}$ emitted from vehicles has a range from $-13 \%$ to $-2 \%$ (Heaton 1990). Long-term deposition of atmospheric $\mathrm{NO}_{\mathrm{x}}$, which was depleted in ${ }^{15} \mathrm{~N}$ (Choi et al. 2005; Kwak et al. 2011) would lead to the negative soil ${ }^{15} \mathrm{~N}$ values observed in our experiment (Choi et al. 2005; Savard et al. 2009). The more negative $\delta^{15} \mathrm{~N}$ signal in soil led to a good differentiation between the $\delta^{15} \mathrm{~N}$ signal derived from the atmosphere in the acacias and the soil derived signal in the reference plants. This could also explain the narrower range of BNF estimation in our study than reported elsewhere when using the ${ }^{15} \mathrm{~N}$ natural abundance method.

Our results also suggested that taxonomic proximity between legume and reference plant may not be necessary as T. triandra, a grass, was able to provide an appropriate $\delta^{15} \mathrm{~N}$ signal. At Site 2 where mature plants were examined, in addition to T. triandra, all other reference plants also gave an appropriate $\delta^{15} \mathrm{~N}$-signal ( $\geq 2 \%$ ). This was within the range recommended by Sanford et al. (1994) but lower than the 5\%o suggested by Hogberg (1997). Taxonomic proximity between legume and reference plant was considered as an important factor to obtain accurate results for BNF estimation (Boddey et al. 2000; Gehring and Vlek 2004). However, the successful use of shrubs and herbaceous plants as reference has been also observed in limited studies such as Pareek et al. (1990) and Peoples et al. (1996). Danso et al. (1992) argued that trees and grass take up nutrients from the same soil zone and consequently, the source of $\mathrm{N}$ uptake of both trees and grass could be similar. Therefore, woody reference plant and grass give the same $\delta^{15} \mathrm{~N}$-signal even though both have different root structures. Different mycorrhizae species associated with plant may be resulted in providing different $\delta^{15} \mathrm{~N}$ signals in plants. If woody plants and grasses have the same mycorrhizae species, they may be providing similar $\delta^{15} \mathrm{~N}$ signals (Evans 2001). Further work was required to clarify this observation, using different species of grasses and shrubs and examining soil $\mathrm{N}$ availability in time and space.

Our study indicated that potential $B$ values ranging from $-0.3 \%$ to $1.0 \%$ could be used to provide an acceptable $\%$ Ndfa estimation for Acacia species based on ${ }^{15} \mathrm{~N}$ natural abundance method in sub-tropical native forests. To our knowledge, a range of $B$ values from $0.0 \%$ to $-1.3 \%$ have successfully been already used to estimate $\mathrm{N}_{2}$ fixation for Acacia spp. (Hamilton et al. 1993; Galiana et al. 2002; May and Attiwill 2003).because the $\delta^{15} \mathrm{~N}$ abundance of atmospheric $\mathrm{N}$ was assumed to be $0.0 \%$ (Okito et al. 2004). This assumed that the amount of fractionation occurring was negligible when atmospheric $\mathrm{N}_{2}$ was fixed. Hamilton et al. (1993) successfully applied a $B$ value of $0.0 \%$ to quantify BNF in $A$. 
mucronata and A. melanoxylon and accepted a minor error when $B$ value of a species had not been determined. Guinto et al. (2000) reported a $B$ value of $-0.04 \%$ for $A$. leiocalyx which would support our decision to choose $B$ value of $0.0 \%$ for BNF determination.BNF activities of legumes may be increased in less fertile soil (Galiana et al. 2002) to compensate for soil $\mathrm{N}$ limitation. In the present study, the high BNF activity indicated at Site 2 suggests a low N availability despite the fact that this area had not been burned for 8 years. Soil $\mathrm{N}$ availability slowly increased following fire through litter-fall decomposition and \%Ndfa in legumes decreased as plants start taking up $\mathrm{N}$ from soil (van Kessel et al. 1994). However, our study indicated a continuing reliance on BNF, which may suggest that this ecosystem requires a longer period to recycle $\mathrm{N}$ and to recover from fire. Increasing fire frequency, which has been predicted as a consequence of global climate change, may result in decreasing soil fertility and increasing ecosystem vulnerability.

\subsection{Plant physiological status and $\mathrm{N}_{2}$ fixation}

Plant physiological status may be used as another indicator of $\mathrm{N}_{2}$ fixation because $A$. leiocalyx consistently indicated greater $A_{\mathrm{n}}, E$, iWUE and TN as well as BNF than those of $A$. disparimma throughout the sampling period. Other studies have determined that there was a positive linear relationship between foliar $A_{\mathrm{n}}$ and BNF activities (Kitaoka and Koike 2004; Kaschuk et al. 2009). Higher BNF activity in A. leiocalyx may have provided more $\mathrm{N}$ for photosynthesis. $\mathrm{N}$ is a vital component of Rubisco, a pivotal enzyme to fix $\mathrm{CO}_{2}$ in the photosynthetic system and enhanced foliar $\mathrm{N}$ concentration with increases photosynthetic capacity in plants (Evans 1989). In our study, there was a poor correlation between \%Ndfa and physiological traits such as $A_{\mathrm{n}}$ and WUE. A high-within treatment variation may have masked the relationships between plant BNF activities and photosynthesis or WUE.

A. leiocalyx showed greater WUE, reflected through higher $\delta^{13} \mathrm{C}$ values and higher iWUE, than A. disparimma. Higher WUE may suggest that A. leiocalyx would be able to alter the strategy of water use with drought stress as argued by Otieno et al. (2005) and Raddad \& Lunkkanen (2006), using this factor as a tool of adaptation to climate change. Increased $\mathrm{N}$ could enhance $A_{\mathrm{n}}$ and WUE. Therefore, higher BNF in A. leiocalyx may have played an important role to increase $A_{\mathrm{n}}$ and WUE and resulted in higher growth rates (data not presented) and consequently higher $\mathrm{C}$ sinks from atmosphere to the earth. Enhanced temperature and prolonged drought may decrease photosynthesis due to increased stomatal closure (Otieno et al. 2005) and plants that have the ability to alter their nutrient and water use strategies may be better able to deal with the adverse impacts of climate change. 


\section{Conclusions}

This study demonstrated that both ${ }^{15} \mathrm{~N}$ enrichment and ${ }^{15} \mathrm{~N}$ natural abundance techniques may be used to estimate $\mathrm{N}_{2}$ fixation of acacia tree species. The ${ }^{15} \mathrm{~N}$ natural abundance technique was preferred to be used for future studies as it was simple and inexpensive and the use of this method facilitated in the present study due to identifying a wider range of reference plants and narrowing down of $B$ values for acacias in native forest. The atmospheric $\mathrm{N}$ deposition could be a main reason for successful use of the ${ }^{15} \mathrm{~N}$ natural abundance technique leading to provide a good difference of $\delta^{15} \mathrm{~N}$ signal between acacias and reference plants. This could also explain a narrower range of BNF estimation in our study when using the ${ }^{15} \mathrm{~N}$ natural abundance method. The present study also demonstrated that foliar physiological traits such as $A_{\mathrm{n}}, A_{\max }$, iWUE and $E$ of plants may be used to indicate plant ability to fix $\mathrm{N}_{2}$. A. leiocalyx with its greater growth and establishment after fire and higher $\%$ Ndfa in comparison to A. disparimma, may also be able to accelerate $\mathrm{N}$ input to the impoverished soils of the Australian urban forests and improve soil fertility. The immediate impacts of environmental extremes such as prolonged drought and frequent fires on the understorey legumes would be expected less severe on A. leiocalyx than A. disparimma. Therefore, species in which the adaptive capacity is within narrow eco-physiological limits such as $A$. disparimma, would be more likely to become extinct with a consequent reduction in ecosystem biodiversity in response to global climate change and the anticipated more frequent fires.

Acknowledgements The authors would like to gratefully acknowledge the financial support and assistance of Powerlink QLD. The authors are particularly grateful to Ms. Elizabeth Gordon and Marijke Heenan for their technical supports and Mr. Bob Coutts for identifying plant species at the experimental sites.

\section{References}

Adams MA, Simon J, Pfautsch S (2010) Woody legumes: a (re)view from the South. Tree Physiol 30:1072-1082

Androsoff GL, Vankessel C, Pennock DJ (1995) Landscape-scale estimates of dinitrogen fixation by Pisum sativum by ${ }^{15} \mathrm{~N}$ natural abundance and enriched isotope dilution. Biol Fert Soils 20:33-40 
Aranjuelo I, Irigoyen JJ, Sánchez-Díaz M (2007) Effect of elevated temperature and water availability on $\mathrm{CO}_{2}$ exchange and nitrogen fixation of nodulated alfalfa plants. Env Exp Bot 59:99-108

Blumfield TJ, Xu ZH (2003) Impact of harvest residues on soil mineral nitrogen dynamics following clearfall harvesting of a hoop pine plantation in subtropical Australia. For Ecol Manage 179:55-67

Blumfield TJ, Xu ZH, Prasolova NV, Mathers NJ (2006) Effect of overlying windrowed harvest residues on soil carbon and nitrogen in hoop pine plantations of subtropical Australia. J Soils Sediments 6:243-248

Boddey RM, Peoples MB, Palmer B, Dart PJ (2000) Use of the ${ }^{15} \mathrm{~N}$ natural abundance technique to quantify biological nitrogen fixation by woody perennials. Nutri Cyc Agroecosys 57:235-270

Bouillet JP, Laclau JP, Goncalves JLM, Moreira MZ, Trivelin PCO, Jourdan C, Silva EV, Piccolo MC, Tsai SM, Galiana A (2008) Mixed-species plantations of Acacia mangium and Eucalyptus grandis in Brazil 2: Nitrogen accumulation in the stands and biological $\mathrm{N}_{2}$ fixation. For Ecol Manage 255:3918-3930

Burton J, Chen CR, Xu ZH, Ghadiri H (2007) Gross nitrogen transformations in adjacent native and plantation forest's of subtropical Australia. Soil Biol Biochem 39:426-433

Catterall CP, Wallace CP, Griffith University. Institute of Applied Environmental Research. (1987) An Island in Suburbia : the Natural and Social History of Toohey Forest. Institute of Applied Environmental Research, Griffith University, Nathan, Qld.

Choi W-J, Lee S-M, Chang SX, Ro H-M (2005) Variations of $\delta^{13} \mathrm{C}$ and $\delta^{15} \mathrm{~N}$ in Pinus densiflora tree-rings and their relationship to environmental changes in eastern Korea. Water Air Soil Poll 164:173-187

Crutzen PJ, Andreae MO (1990) Biomass burning in the tropics - impact on atmospheric chemistry and biogeochemical cycles. Science 250:1669-1678

Danso SKA, Bowen GD, Sanginga N (1992) Biological nitrogen fixation in trees in agroecosystems. Plant Soil 141:177-196

Evans RD (2001) Physiological mechanisms influencing plant nitrogen isotope composition.

Trends Plant Science 6:121-126Evans JR (1989) Photosynthesis and nitrogen relationships in leaves of C-3 plants. Oecologia 78:9-19

Farquhar GD, Richards RA (1984) Isotopic composition of plant carbon correlates with water-use efficiency in wheat genotypes. Aus J Plant Physiol 11:539-552 
Forrester DI, Bauhus J, Cowie AL, Vanclay JK (2006) Mixed-species plantations of Eucalyptus with nitrogen-fixing trees: A review. For Ecol and Manage 233:211-230

Fried M, Middelboe V (1977) Measurement of amount of nitrogen fixed by legume crop. Plant Soil 43:713-715

Fujita K, Masuda T, Ogata S (1988) Dinitrogen fixation, ureide concentration in xylem exudate and translocation of photosynthates in soybean as influenced by ood removal and defoliation. Soil Sci Plant Nutri 34:265-275

Galiana A, Balle P, Kanga AN, Domenach AM (2002) Nitrogen fixation estimated by the ${ }^{15} \mathrm{~N}$ natural abundance method in Acacia mangium Willd. inoculated with Bradyrhizobium sp. and grown in silvicultural conditions. Soil Biol Biochem 34:251-262

Gehring C, Vlek PLG (2004) Limitations of the ${ }^{15} \mathrm{~N}$ natural abundance method for estimating biological nitrogen fixation in Amazonian forest legumes. Basic App Ecol 5:567-580

Guerrieri MR, Siegwolf RTW, Saurer M, Jäggi M, Cherubini P, Ripullone F, Borghetti M (2009) Impact of different nitrogen emission sources on tree physiology as assessed by a triple stable isotope approach. Atmos Env 43:410-418

Guinto DF, Xu ZH, House APN, Saffigna PG (2000) Assessment of $\mathrm{N}_{2}$ fixation by understorey acacias in recurrently burnt eucalypt forests of subtropical Australia using ${ }^{15} \mathrm{~N}$ isotope dilution techniques. Can J For Res 30:112-121

Hamilton SD, Hopmans P, Chalk PM, Smith CJ (1993) Field estimation of $\mathrm{N}_{2}$ fixation by Acacia Spp. using ${ }^{15} \mathrm{~N}$ isotope dilution and labeling with $\mathrm{S}_{35}$. For Ecol Manage $56: 297-313$

Hansen AP, Pate JS (1987) Evaluation of the ${ }^{15} \mathrm{~N}$ natural abundance method and xylem sap analysis for assessing $\mathrm{N}_{2}$ fixation of understorey legumes in jarrah (Eucalyptus marginata Donn-Ex-Sm) forest in SW Australia. J Exp Bot 38:1446-1458

Heaton THE (1990) 15N/14N ratios of NOx from vehicle engines and coal-fired power stations. Tellus B 42:304-307

Hogberg P (1997) Tansley Review No $95-{ }^{15} \mathrm{~N}$ natural abundance in soil-plant systems. New Phytol 137:179-203

Høgh-Jensen H, Schjoerring JK (1994) Measurement of biological dinitrogen fixation in grassland: Comparison of the enriched ${ }^{15} \mathrm{~N}$ dilution and the natural ${ }^{15} \mathrm{~N}$ abundance methods at different nitrogen application rates and defoliation frequencies. Plant Soil 166:153-163

Hopmans P, Stewart HTL, Flinn DW (1993) Impacts of harvesting on nutrients in a eucalypt ecosystem in Southeastern Australia. For Ecol Manage 59:29-51 
Houngnandan P, Yemadje R, Oikeh S, Djidohokpin C, Boeckx P, Van Cleemput O (2008) Improved estimation of biological nitrogen fixation of soybean cultivars (Glycine max L. Merril) using 15N natural abundance technique. Biol Fert Soils 45:175-183

Imsande J (1988) Enhanced nitrogen fixation increases net photosynthetic output and seed yield of hydroponically grown soybean. J Exp Bot 39:1313-1321

Jung M, Reichstein M, Ciais P, Seneviratne SI, Sheffield J, Goulden ML, Bonan G, Cescatti A, Chen JQ, de Jeu R, Dolman AJ, Eugster W, Gerten D, Gianelle D, Gobron N, Heinke J, Kimball J, Law BE, Montagnani L, Mu QZ, Mueller B, Oleson K, Papale D, Richardson AD, Roupsard O, Running S, Tomelleri E, Viovy N, Weber U, Williams C, Wood E, Zaehle S, Zhang K (2010) Recent decline in the global land evapotranspiration trend due to limited moisture supply. Nature 467:951-954

Kaschuk G, Kuyper TW, Leffelaar PA, Hungria M, Giller KE (2009) Are the rates of photosynthesis stimulated by the carbon sink strength of rhizobial and arbuscular mycorrhizal symbioses? Soil Biol Biochem 41:1233-1244

Kitaoka S, Koike T (2004) Invasion of broad-leaf tree species into a larch plantation: seasonal light environment, photosynthesis and nitrogen allocation. Physiol Planta 121:604-611

Koopmans CJ, Dam DV, Tietema A, Verstraten JM (1997) Natural ${ }^{15} \mathrm{~N}$ abundance in two nitrogen saturated forest ecosystems. Oecologia 111:470-480

Kwak J-H, Lim S-S, Chang S, Lee K-H, Choi W-J (2011) Potential use of $\delta^{13} \mathrm{C}, \delta^{15} \mathrm{~N}, \mathrm{~N}$ concentration, and $\mathrm{Ca} / \mathrm{Al}$ of Pinus densiflora; tree rings in estimating historical precipitation $\mathrm{pH}$. J Soils Sediments 11:709-721

Ladha JK, Peoples MB, Garrity DP, Capuno VT, Dart PJ (1993) Estimating dinitrogen fixation of hedgerow vegetation using the ${ }^{15} \mathrm{~N}$ natural abundance method. Soil Sci Soc Am J 57:732-737

Lambers H, Chapin FS, Pons TL (2008) Plant Physiological Ecology. Springer-Verlag, NewYork,NY,USA

May BM, Attiwill PM (2003) Nitrogen fixation by Acacia dealbata and changes in soil properties 5 years after mechanical disturbance or slash burning following timber harvest. For Ecol Manage 181:339-355

McKeon GM, Stone GS, Syktus JI, Carter JO, Flood NR, Ahrens DG, Bruget DN, Chilcott CR, Cobon DH, Cowley RA, Crimp SJ, Fraser GW, Howden SM, Johnston PW, Ryan JG, Stokes CJ, Day KA (2009) Climate change impacts on northern Australian rangeland livestock carrying capacity: a review of issues. Rangeland J 31:1-29 
Naab J, Chimphango S, Dakora F (2009) $\mathrm{N}_{2}$ fixation in cowpea plants grown in farmers' fields in the Upper West Region of Ghana, measured using15N natural abundance. Symbiosis 48:37-46

Okito A, Alves B, Urquiaga S, Boddey RM (2004) Isotopic fractionation during $\mathrm{N}_{2}$ fixation by four tropical legumes. Soil Biol Biochem 36:1179-1190

Otieno DO, Schmidt MWT, Kinyamario JI, Tenhunen J (2005) Responses of Acacia tortilis and Acacia xanthophloea to seasonal changes in soil water availability in the savanna region of Kenya. J Arid Env 62:377-400

Pareek RP, Ladha JK, Watanabe I (1990) Estimating $\mathrm{N}_{2}$ fixation by Sesbania rostrata and $S$. cannabina (Syn S. aculeata) in lowland rice soil by the ${ }^{15} \mathrm{~N}$ dilution method. Biol Fert Soils 10:77-88

Parrotta JA, Baker DD, Fried M (1994) Application of ${ }^{15} \mathrm{~N}$ enrichment methodologies to estimate nitrogen fixation in Casuarina equisetifolia. Can J For Res 24:201-207

Peoples MB, Faizah AW, Rerkasem B, Herridge DF (eds) (1989) Methods for evaluating nitrogen fixation by nodulated legumes in the field. ACIAR monograph series ; 11 . Australian Centre for Internatioal Agricultural Research, Canberra

Peoples MB, Palmer B, Lilley DM, Duc LM, Herridge DF (1996) Application of ${ }^{15} \mathrm{~N}$ and xylem ureide methods for assessing $\mathrm{N}_{2}$ fixation of three shrub legumes periodically pruned for forage. Plant Soil 182:125-137

Prasolova NV, Xu ZH, Farquhar GD, Saffigna PG, Dieters MJ (2000) Variation in canopy C13 of 8-year-old hoop pine families (Araucaria cunninghamii) in relation to canopy nitrogen concentration and tree growth in subtropical Australia. Tree Physiol 20:1049-1055

Raddad EAY, Luukkanen O (2006) Adaptive genetic variation in water use efficiency and gum yield in Acacia senegal provenances grown on clay soil in the Blue Nile region, Sudan. For Ecol Manage 226:219-229

Reverchon F, Xu ZH, Blumfield TJ, Chen CR, Abdullah KM (2011) Impact of global climate change and prescribed burning on understorey legumes and associated belowground communities: implications for biogeochemical cycles in forest ecosystems. J Soils Sediments DOI 10.1007/s11368-011-0445-1

Sanford P, Pate JS, Unkovich MJ (1994) A survey of proportional dependence of subterranean clover and other pasture legumes on $\mathrm{N}_{2}$ fixation in South-West Australia utilizing ${ }^{15} \mathrm{~N}$ natural-abundance. Aus J Agr Res 45:165-181 
Savard M, B’egin C, Smirnoff A (2009) Tree-ring nitrogen isotopes reflect anthropogenic NOX emissions and climatic effects. Env Sci Tech 43:604-609

Shearer G, Kohl DH (1986) $\mathrm{N}_{2}$ fixation in field settings: estimations based on natural ${ }^{15} \mathrm{~N}$ abundance. Aus J Plant Physiol 13:699-756

Somado EA, Kuehne RF (2006) Appraisal of the ${ }^{15} \mathrm{~N}$ isotope dilution and ${ }^{15} \mathrm{~N}$ natural abundance methods for quantifying nitrogen fixation by flood-tolerant green manure legumes. Afri J Biotech 5:1210-1214

Stevenson FC, Knight JD, Vankessel C (1995) Dinitrogen fixation in pea - controls at the landscape-scale and microscale. Soil Sci Soc Am J 59:1603-1611

Thonicke K, Spessa A, Prentice IC, Harrison SP, Dong L, Carmona-Moreno C (2010) The influence of vegetation, fire spread and fire behaviour on biomass burning and trace gas emissions: results from a process-based model. Biogeosciences 7:1991-2011

Unkovich MJ, Pate JS (2000) An appraisal of recent field measurements of symbiotic $\mathrm{N}_{2}$ fixation by annual legumes. Field Crops Res 65:211-228

Unkovich MJ, Pate JS, Lefroy EC, Arthur DJ (2000) Nitrogen isotope fractionation in the fodder tree legume tagasaste (Chamaecytisus proliferus) and assessment of $\mathrm{N}_{2}$ fixation inputs in deep sandy soils of Western Australia. Aus J Plant Physiol 27:921929

van Kessel C, Farrel RE, Roskoski JP, Keane KM (1994) Recycling of the naturallyoccurring $15 \mathrm{~N}$ in an established stand of Leucaena leucocephala. Soil Biol Biochem 26:757-762

Warembourg FR (1993) Nitrogen fixation in soil and plant systems. In: Knowles R, Blackburn TH (eds) Nitrogen Isotope Techniques. Academic Press, INC, London, pp $127-156$

Xiao H-Y, Tang C-G, Xiao H-W, Liu X-Y, Liu C-Q (2010) Stable sulphur and nitrogen isotopes of the moss Haplocladium microphyllum at urban, rural and forested sites. Atmos Env 44:4312-4317

Xiao HY, Liu CQ (2002) Sources of nitrogen and sulfur in wet deposition at Guiyang, southwest China. Atmos Env 36:5121-5130

Xu ZH, Chen CR, He JZ, Liu JX (2009) Trends and challenges in soil research 2009: linking global climate change to local long-term forest productivity. J Soils Sediments 9:8388

Xu ZH, Prasolova NV, Lundkvist K, Beadle C, Leaman T (2003) Genetic variation in branchlet carbon and nitrogen isotope composition and nutrient concentration of 11- 
year-old hoop pine families in relation to tree growth in subtropical Australia. For Ecol Manage 186:359-371

Xu ZH, Saffigna PG, Farquhar GD, Simpson JA, Haines RJ, Walker S, Osborne DO, Guinto D (2000) Carbon isotope discrimination and oxygen isotope composition in clones of the F-1 hybrid between slash pine and Caribbean pine in relation to tree growth, water-use efficiency and foliar nutrient concentration. Tree Physiol 20:1209-1217 
Table 1: Soil chemical properties and particle component at Sites 1 and 2 located at Toohey Forest collected from experimental plots at depth 0-10 cm in April 2009.

\begin{tabular}{|c|c|c|c|c|c|c|c|c|}
\hline & \multicolumn{5}{|c|}{ Soil chemical properties $^{\mathrm{a}}$} & \multicolumn{3}{|c|}{ Soil particle component } \\
\hline & $\mathrm{pH}$ & $\mathrm{TC}(\%)$ & $\mathrm{TN}(\%)$ & $\mathrm{C}: \mathrm{N}$ & $\delta^{15} \mathrm{~N}(\%)$ & Clay (\%) & Silt (\%) & Sand $(\%)$ \\
\hline Site 1 & $5.07(0.05)$ & $2.71(0.20)$ & $0.10(0.00)$ & $13.5(1.0)$ & $-0.83(0.42)$ & $25.9(0.66)$ & $26.0(0.42)$ & $47.9(0.46)$ \\
\hline Site 2 & $4.92(0.10)$ & $3.32(0.14)$ & $0.12(0.02)$ & $12.4(1.3)$ & $-0.92(0.30)$ & $19.9(1.20)$ & $23.6(0.40)$ & $56.4(0.84)$ \\
\hline
\end{tabular}

${ }^{a}$ Soil chemical properties include: soil total $\mathrm{C}(\mathrm{TC})$, total $\mathrm{N}(\mathrm{TN}), \mathrm{C}: \mathrm{N}$ ratio and $\mathrm{N}$ isotope composition $\left(\delta^{15} \mathrm{~N}\right)$

Numbers in the brackets denote standard errors. 
Table 2: Nitrogen isotope composition $\left(\delta^{15} \mathrm{~N} \%\right.$ ) of Acacia spp. and reference plants during three seasons.

\begin{tabular}{|c|c|c|c|c|c|c|}
\hline \multirow{3}{*}{ Plant Species } & \multicolumn{6}{|c|}{$\delta^{15} \mathrm{~N}(\%)$} \\
\hline & \multicolumn{3}{|c|}{ Site 1} & \multicolumn{3}{|c|}{ Site 2} \\
\hline & Season 1 & Season 2 & Season 3 & Season 1 & Season 2 & Season 3 \\
\hline A. disparimma & $-0.73(0.14)$ & $-1.06(0.19)$ & $-1.26(0.15)$ & $-0.82(0.13)$ & $-1.53(0.11)$ & $-1.28(0.10)$ \\
\hline E. planchoniana & $-1.87(1.39)^{*}$ & $-5.73(0.65)^{*}$ & $-3.78(0.54) *$ & & & \\
\hline E. carnea & & & & $-5.40(0.18)^{*}$ & $-6.48(0.07) *$ & $-3.39(0.16) *$ \\
\hline E. tindaliae & $-0.65(0.05)$ & $-4.39(0.00) *$ & $-5.26(0.00) *$ & $-3.50(0.00) *$ & $-5.74(0.00) *$ & $-3.45(0.00) *$ \\
\hline E. resinifera & $-0.30(2.9)$ & $-4.40(0.00) *$ & $-2.04(0.72) *$ & $-4.25(0.75) *$ & $-6.42(0.68) *$ & $-4.31(0.00) *$ \\
\hline Corymbia henryi & & & & $-4.93(0.43) *$ & $-7.05(0.18) *$ & $-3.94(0.24) *$ \\
\hline
\end{tabular}

Mean standard errors are in parentheses

$* \mathrm{P}<0.05$ level indicates a significant difference in $\delta 15 \mathrm{~N}$ between Acacia spp. and reference plants 


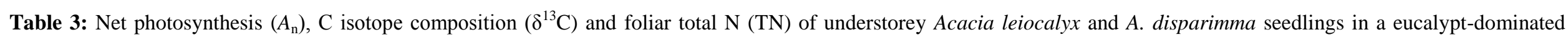
urban forest of subtropical Australia.

\begin{tabular}{|c|c|c|c|c|c|c|c|c|c|}
\hline \multirow{2}{*}{ Species $\uparrow$} & \multicolumn{3}{|c|}{$A_{\mathrm{n}}\left(\mu \mathrm{mol} \mathrm{m}{ }^{-2} \mathrm{~s}^{-1}\right)$} & \multicolumn{3}{|c|}{$\delta^{13} \mathrm{C}(\%)$} & \multicolumn{3}{|c|}{$\mathrm{TN}(\%)$} \\
\hline & Season 1 & Season 2 & Season 3 & Season 1 & Season 2 & Season 3 & Season 1 & Season 2 & Season 3 \\
\hline A. leiocalyxs & $16.2(0.86)^{*}$ & $15.0(1.20)^{*}$ & $18.8(1.25)^{*}$ & $-31.9(0.29) a b$ & $-32.7(0.21) b$ & $-31.4(0.27) \mathrm{a}$ & $2.50(0.11)$ & $2.68(0.16)$ & $2.50(0.16)^{*}$ \\
\hline A. disparimma & $12.8(0.53)$ & $11.3(0.46)$ & $11.9(0.67)$ & $-32.0(0.25) \mathrm{a}$ & $-32.8(0.20) b$ & $-31.9(0.18) \mathrm{a}$ & $2.40(0.06)$ & $2.50(0.07)$ & $2.05(0.07)$ \\
\hline
\end{tabular}

Means followed by the lower case letters within same row for each variable demonstrate the significant difference in seasons at the level $\mathrm{P}<0.05$.

Means followed by no lower case letters within same row for each variable demonstrate no significant difference in seasons at the level $\mathrm{P}<0.05$

$\dagger$ Interactions between seasons and species were not significant for all variables

$* \mathrm{P}<0.05$ level indicates a significant difference between two species at the sampling season 
Fig. 1 Monthly rainfall $(\mathrm{mm})$ (grey columns) and monthly mean daily maximum temperature $\left({ }^{\circ} \mathrm{C}\right)(\mathbf{\square})$ of the experimental site, Toohey Forest from January 2009 to March 2010.

Fig. 2 Percentage of $\mathrm{N}$ derived from atmosphere (\% $\mathrm{Ndfa})$ of understorey Acacia leiocalyx (white columns) and A. disparimma (grey columns) seedlings at Site 1 using ${ }^{15} \mathrm{~N}$ enrichment and ${ }^{15} \mathrm{~N}$ natural abundance methods (a and $\mathrm{b}$ ) and at Site 2 using ${ }^{15} \mathrm{~N}$ natural abundance (c) in a eucalypt-dominated urban forest of subtropical Australia. * indicates significant differences between two species at the level $P<0.05$. Bars are means \pm standard errors.

Fig. 3 Maximum photosynthesis $-A_{\max }$ (a), transpiration $-E$ (b) and instantaneous water use efficiency - iWUE (c) of understorey Acacia leiocalyx (white columns) and A. disparimma (grey columns) seedlings in a eucalypt dominated urban forest of subtropical Australia. The * indicates significant differences between two species at the level $P<0.05$. Bars are means \pm standard errors.

Fig. 4 Relationship between foliar total $\mathrm{N}(\mathrm{TN})$ and net photosynthesis $\left(A_{\mathrm{n}}\right)$ (a) and between $\mathrm{TN}$ and percentage of $\mathrm{N}$ derived from atmosphere (\%Ndfa) (b) in a eucalyptdominated urban forest of subtropical Australia. 
Fig. 1

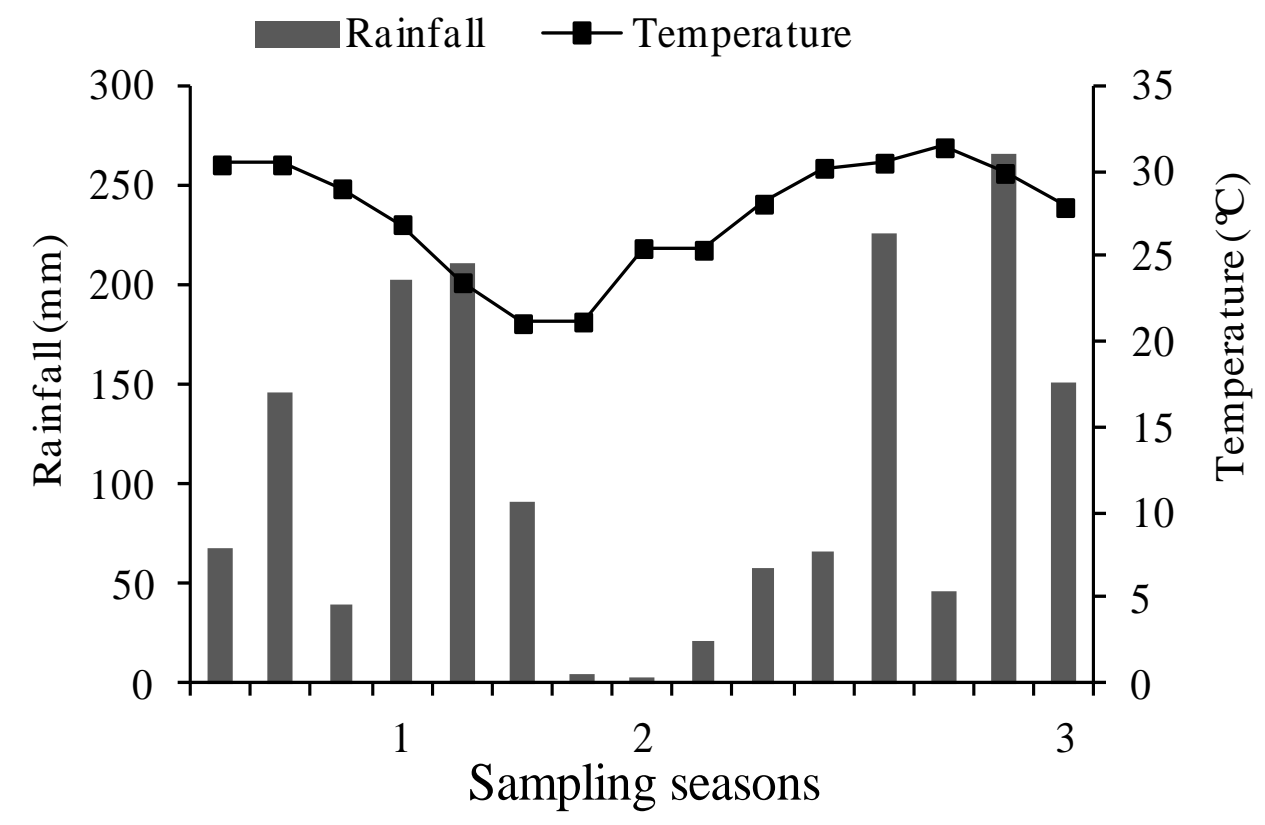


Fig. 2
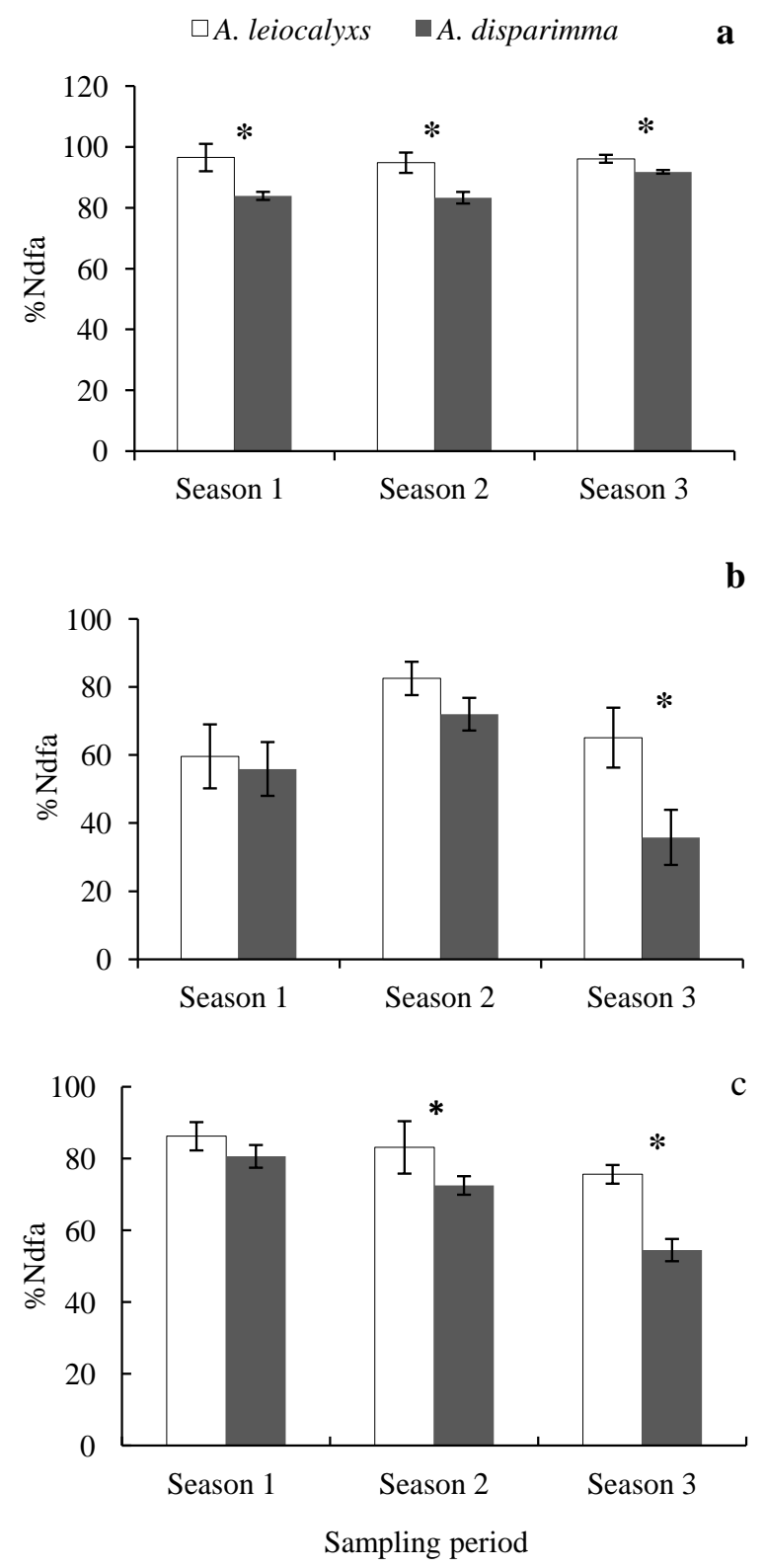
Fig. 3
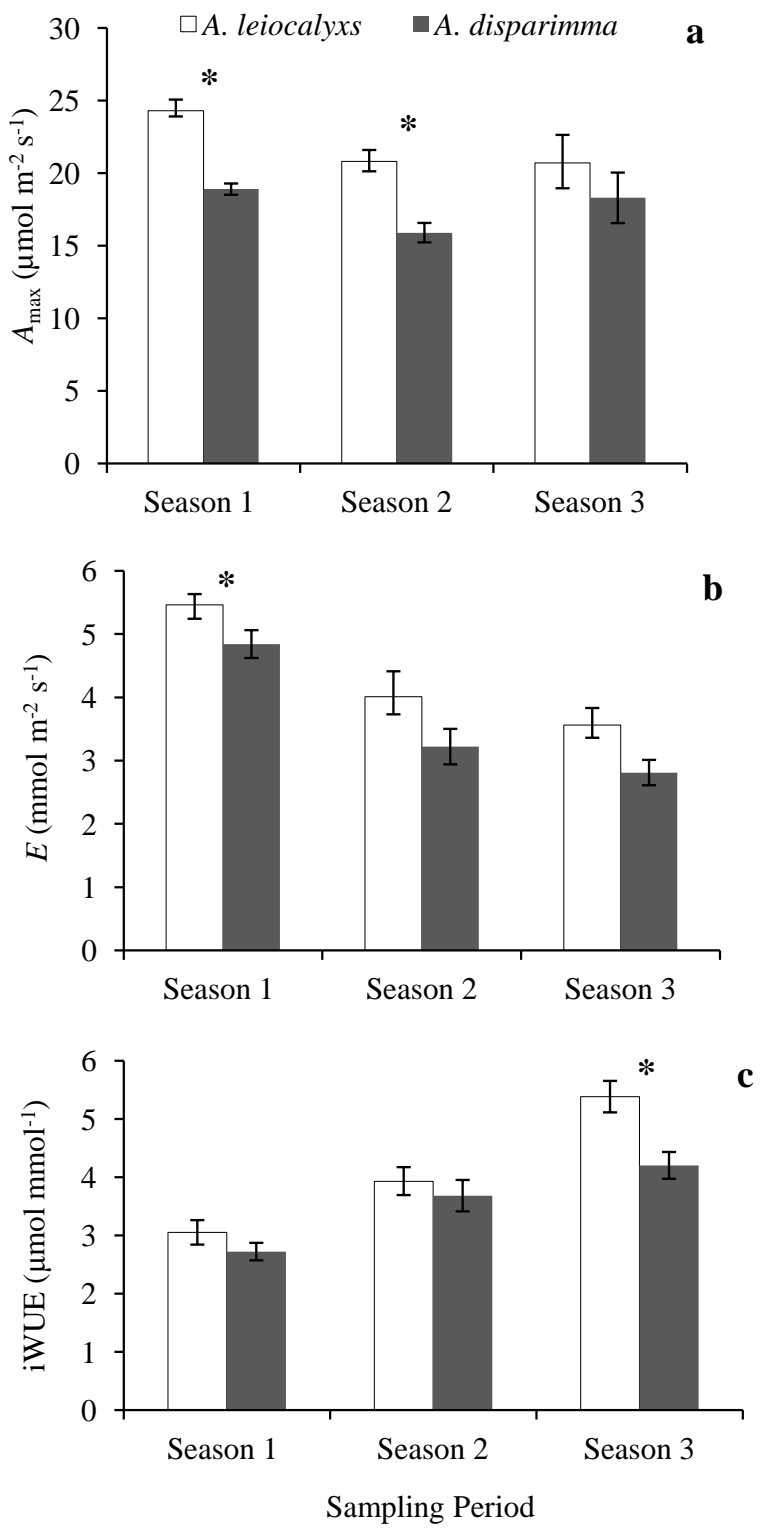
Fig. 4

a
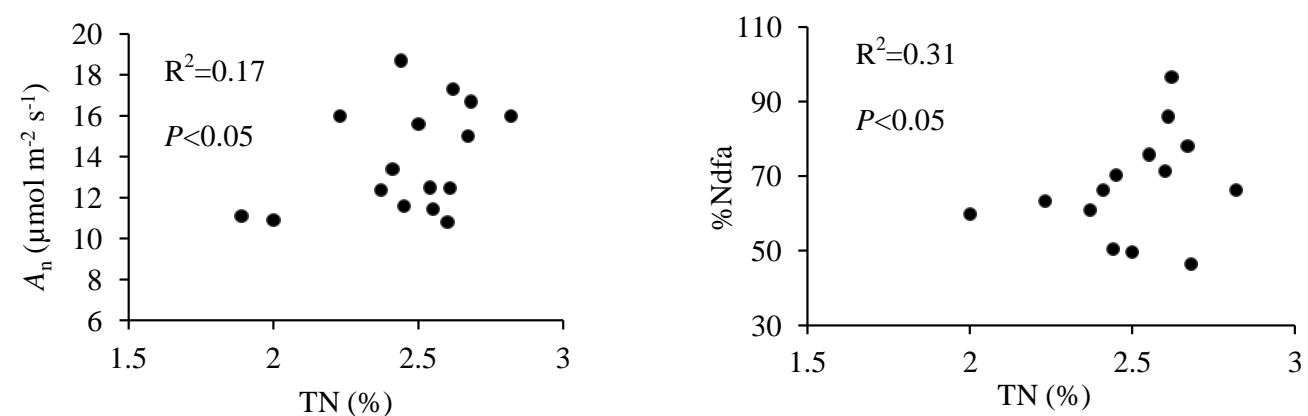